\title{
Biomass Production and Pigment Accumulation in Kale Grown Under Different Radiation Cycles in a Controlled Environment
}

\author{
Mark G. Lefsrud ${ }^{1}$ and Dean A. Kopsell ${ }^{2,3}$ \\ Plant Sciences Department, The University of Tennessee, Knoxville, \\ TN 37996
}

Additional index words. $\beta$-carotene, Brassica oleracea, carotenoid, irradiance, lutein, nutrition

\begin{abstract}
Controlled plant growing systems have consistently used the standard earth day as the radiation cycle for plant growth. However, the radiation cycle can be controlled using automated systems to regulate the exact amount of time plants are exposed to irradiation (and darkness). This experiment investigated the influence of different radiation cycle periods on plant growth and carotenoid accumulation in kale (Brassica oleracea L. var. acephala DC.). Plants were grown in a controlled environment using nutrient solutions under radiation cycle treatments of $2,12,24$ and 48 hours, with $50 \%$ irradiance and $50 \%$ darkness during each cycle. The radiation cycles significantly affected kale fresh weight, dry weight, percent dry matter, and the accumulation of lutein, $\beta$-carotene, and chlorophyll $a$ and $b$. Maximum fresh weight occurred under the 2-hour radiation cycle treatment, whereas maximum dry weight occurred under the 12-hour treatment. Maximum accumulation of lutein, $\beta$-carotene, and chlorophyll $a$ occurred with the 12 -hour radiation cycle at values of $14.5 \mathrm{mg} / 100 \mathrm{~g}, 13.1 \mathrm{mg} / 100 \mathrm{~g}$, and $263.3 \mathrm{mg} / 100 \mathrm{~g}$ fresh weight respectively. Maximum fresh weight production of the kale was not linked to increases in chlorophyll, lutein, or $\beta$-carotene. Consumption of fruit and vegetable crops rich in lutein and $\beta$-carotene carotenoids is associated with reduced risk of cancers and aging eye diseases. Increased carotenoid concentrations in vegetable crops would therefore be expected to increase the value of these crops.
\end{abstract}

Plants on earth have evolved to maximize efficiency of growth and development at a radiation cycle of $24 \mathrm{~h}$, with fluctuations occurring during the length of the photoperiods. Contrast this with the moon, where the radiation cycle consists of $14 \mathrm{~d}$ of irradiance and $14 \mathrm{~d}$ of darkness for a total radiation cycle of $28 \mathrm{~d}$. This paper defines radiation cycle as the hypothetical rotation of a planetary body relative to the sun. The growth of plants under controlled environments is not confined to the standard earth day, and past research has investigated the influence of irradiance on growth parameters. Radiation cycles are of importance because plants use irradiance cues as signals to determine such things as bud formation, flowering, leaf emergence, and germination (Densmore, 1997; Gottdenker et al., 2000; Riihimaki and Savolainen, 2004). In general, increases

\footnotetext{
Received for publication 10 May 2006. Accepted for publication 26 June 2006. This paper was funded in part by a grant received by the Cooperative State Research, Education, and Extension Service, U.S. Department of Agriculture, under agreement no. 2001-52102-11254.We thank Joanne Curran-Celentano and Joe Sheehan for their help during this project.

${ }^{1}$ Former Graduate Research Assistant.

${ }^{2}$ Assistant Professor.

${ }^{3}$ To whom reprint requests should be addressed; e-maildkopsell@utk.edu.
}

in irradiance periods result in increases in plant biomass production. Moreover, many crop plants maximize biomass accumulations under continuous irradiance (Garner and Allard, 1931; Koontz and Prince, 1986; Lefsrud et al., 2006).

There is conflicting literature on plant developmental responses when radiation cycles are changed compared with naturally existing photoperiods. Some research shows that changes in radiation cycles result in decreased fresh weight, dry weight, chlorophyll content, stem elongation, and leaf area (Berry et al., 1986; Bonde, 1955, 1956; Garner and Allard, 1931; Morrow et al., 1987; Takano et al., 1987). The amount of these decreases is usually dependent upon plant species, variety, and the radiation cycle chosen. Tomatoes, lettuce (Lactuca sativa L.), and wheat (Triticum aestivum L.) biomass decreased when grown under a radiation cycle of $60 \mathrm{~min} / 30 \mathrm{~min}$ (irradiance/dark conditions in a simulated low-earth orbit). Under a radiation cycle of $60 \mathrm{~min} / 30 \mathrm{~min}$, an increase was reported for one variety of wheat (Morrow et al., 1987). Other research points to an increase in plant growth and pigment accumulation under changes in radiation cycles. Tomatoes (Lycopersicon esculentum Mill.) grown with a radiation cycle of $4 \mathrm{~h}$ resulted in greater biomass accumulation than plants grown with a 24 -h radiation cycle (Bonde, 1955).
Carotenoids are $\mathrm{C}_{40}$ isoprenoid compounds that form lipid-soluble yellow, orange, and red pigments in higher plants, bacteria, alga, and fungi (Sandmann, 2001; Zaripheh and Erdman, 2002). They are secondary plant compounds that are divided into two groups: the oxygenated xanthophylls such as lutein $\left(3 R, 3^{\prime} R, 6^{\prime} R \quad \beta, \varepsilon\right.$-carotene$3,3^{\prime}$ diol $)$ and zeaxanthin $\left(3,3^{\prime} \mathrm{R}-\beta, \beta\right.$-carotene-3,3'diol), and the hydrocarbon carotenes such as $\beta$-carotene $(\beta, \beta$-carotene) and lycopene ( $\psi, \psi$-carotene) (Zaripheh and Erdman, 2002). In plants, carotenoids are used as antenna pigments to funnel light energy to the photosynthetic reaction center. Carotenoids are in close proximity to the chlorophyll molecules and absorb energy to prevent damage to the photosynthetic system (Miki, 1991; Tracewell et al., 2001). Dietary intake of foods rich in lutein and $\beta$-carotene has been associated with reduced risk of lung cancer, cataracts, and age-related macular degeneration (Ames et al., 1995; Landrum and Bone, 2001; Le Marchand et al., 1993). The U.S. Department of Agriculture (USDA) nutrient database ranks kale (Brassica oleracea L. var. acephala DC.) as the highest vegetable source of lutein and $\beta$-carotene carotenoids, making it an excellent dietary source of these compounds (Holden et al., 1999; Kurilich et al., 1999; USDA, 2005).

Light is critical for plant growth and development, and irradiance cycles can be controlled by growers in enclosed environments. What remains unclear is the effect of different radiation cycles on the production of plant secondary compounds, such as carotenoids. Therefore, the goal of this study was to investigate responses in biomass production and pigment accumulations in kale grown under different radiation cycles. In addition, it was our intent to determine which radiation cycle treatment resulted in maximum carotenoid concentrations.

\section{Material and Methods}

\section{Plant culture}

'Winterbor' kale (Johnny's Selected Seed, Winslow, Maine) was seeded into rockwool growing cubes (Grodan A/S, Dk-2640, Hedehusene, Denmark) and germinated in a greenhouse $\left(22{ }^{\circ} \mathrm{C}\right.$ day $/ 14{ }^{\circ} \mathrm{C}$ night $)$ under natural lighting conditions (Durham, N.H., lat. $43^{\circ} 09^{\prime} \mathrm{N}$ ) on $18 \mathrm{Feb} ., 23$ Mar., and 8 May 2004. Peter's 20.0N-6.9P-16.6K water-soluble fertilizer (Scotts, Marysville, Ohio) was applied at $200 \mathrm{mg} \cdot \mathrm{L}^{-1}$ every $5 \mathrm{~d}$. After 2 weeks, the plants were transferred to $38-\mathrm{L}$ plastic containers (Rubbermaid, Wooster, Ohio) and grown in accordance with Lefsrud et al. (2005). Eight plants were placed into $2-\mathrm{cm}$ round holes set at $10.6 \times 9.5-\mathrm{cm}$ spacing on each container lid. Four containers were placed into each of four growth chambers (model E15; Conviron, Winnipeg, Manitoba), with containers acting as experimental replications and chambers as experimental treatments. Growth chamber temperature set point was $20 \pm 1{ }^{\circ} \mathrm{C}$. The photosynthetically active radiation $(P A R)$ was measured (QSO-ELEC; 
Apogee Instruments; Logan, Utah) at six locations, without plants, on top of each tub at the four corner plant holes and between the two side middle plant holes, and was averaged. Irradiance levels were measured at the beginning and confirmed at the end of each replication. Cool white fluorescent and incandescent bulbs delivered an average irradiance of $500 \pm 100 \mu \mathrm{mol} \cdot \mathrm{m}^{-2} \cdot \mathrm{s}^{-1}$. Radiation cycle (CYCLE) treatments were 2, 12, 24, and $48 \mathrm{~h}$. For each treatment, the irradiance period was set at $50 \%$ of the cycle duration to produce irradiance-to-dark ratios of 1:1, 6:6, $12: 12$, and $24: 24 \mathrm{~h}$ for the radiation cycles of $2,12,24$, and $48 \mathrm{~h}$ respectively. Total integrated level of irradiance over each experimental run was $453 \pm 90 \mathrm{~mol} \cdot \mathrm{m}^{-2}$. (total experimental duration $)^{-1}$. The bulbs reached $96 \%$ peak output within 5 min. This warmup period resulted in the 2 -h radiation cycle having $0.4 \%$ less light than the other treatments.

The plants were grown in $30 \mathrm{~L}$ nutrient solution (Hoagland and Arnon, 1950). Solution culture elemental concentrations were N (105 mg. $\left.{ }^{-1}\right), P\left(15.3 \mathrm{mg} \cdot \mathrm{L}^{-1}\right), \mathrm{K}$ (117 $\left.\mathrm{mg} \cdot \mathrm{L}^{-1}\right), \mathrm{Ca}\left(80.2 \mathrm{mg} \cdot \mathrm{L}^{-1}\right), \mathrm{Mg}\left(24.6 \mathrm{mg} \cdot \mathrm{L}^{-1}\right)$, $\mathrm{S}\left(32.0 \mathrm{mg} \cdot \mathrm{L}^{-1}\right), \mathrm{Fe}\left(0.5 \mathrm{mg} \cdot \mathrm{L}^{-1}\right), \mathrm{B}(0.25$ $\left.\mathrm{mg} \cdot \mathrm{L}^{-1}\right)$, Mo $\left(0.005 \mathrm{mg} \cdot \mathrm{L}^{-1}\right), \mathrm{Cu}(0.01$ $\left.\mathrm{mg} \cdot \mathrm{L}^{-1}\right), \mathrm{Mn}\left(0.25 \mathrm{mg} \cdot \mathrm{L}^{-1}\right)$, and $\mathrm{Zn}(0.025$ $\mathrm{mg} \cdot \mathrm{L}^{-1}$ ). The electrical conductivity (EC) of the starting nutrient solution was $0.7 \mathrm{mS} \cdot \mathrm{cm}^{-1}$ and $\mathrm{pH}$ was measured at 5.6. Nutrient solutions were replaced every week throughout the experiment to eliminate potential $\mathrm{pH}$ drift and to refresh solutions to initial nutrient concentrations. Solutions were aerated with an air blower (model 25E133W222; Spencer, Winsor, Conn.) connected to air stones. Deionized water was added daily to maintain $30 \mathrm{~L}$ in each container.

During each experimental replication, plants were grown for $21 \mathrm{~d}$ and harvested on 25 Mar., 27 Apr., and 12 June 2004. At harvest, shoot and root tissues were separated and weighted. The fourth expanded leaf from the crown was selected and a $4-\mathrm{cm}^{2}$ piece was removed from each of eight plants in each container and then combined to form one sample. Samples were stored at $-80^{\circ} \mathrm{C}$ before lyophilization. Shoot material was dried at $60{ }^{\circ} \mathrm{C}$ for no less than $72 \mathrm{~h}$, at which time shoot dry weight was calculated.

\section{Carotenoid and chlorophyll determination: Tissue extraction}

Frozen kale samples were lyophilized for a minimum of 72 h 6 (6L FreeZone; LabConCo, Kansas City, Mo.). Pigments were extracted and separated according to Kopsell et al. (2004) - a procedure based on the method of Khachik et al. (1986). A 0.1-g subsample was placed into a Potter-Elvehjem tissue grinder tube (Kontes, Vineland, N.J.) and hydrated with $0.8 \mathrm{~mL}$ deionized water. The sample was placed in a $40{ }^{\circ} \mathrm{C}$ water bath for $20 \mathrm{~min}$. After hydration, $0.8 \mathrm{~mL}$ of an internal standard, ethyl- $\beta$-apo- $8^{\prime}$-carotenoate (Sigma Chemical Co., St. Louis) and $2.5 \mathrm{~mL}$ of highperformance liquid chromatography (HPLC) grade tetrahydrofuran (THF) were added to the sample. The sample was homogenized in the tube with $\approx 25$ insertions with a PotterElvehjem tissue grinder pestle attached to a drill press (Sears, Roebuck and Co., Hoffman Estates, Ill.) at $540 \mathrm{rpm}$. The sample tube was kept immersed in ice to dissipate excess heat from frictions. The tube was placed into a centrifuge (model 225; Fisher Scientific, Suwanee, Ga.) for $3 \mathrm{~min}$ at $500 \mathrm{~g}_{\mathrm{n}}$. The supernatant was removed with a Pasteur pipet, placed into a conical $15-\mathrm{mL}$ test tube, capped, and held on ice. The sediment was resuspended in $2.0 \mathrm{~mL}$ THF and homogenized with $\approx 25$ insertions of the grinding pestle. The tube was centrifuged for $3 \mathrm{~min}$ at $500 \mathrm{~g}_{\mathrm{n}}$, and the supernatant was collected and combined with the first extracted supernatant. The extraction procedure was repeated twice more until the supernatant was colorless. The sediment was discarded and the combined four supernatants were placed in a $40{ }^{\circ} \mathrm{C}$ water bath and reduced to $0.5 \mathrm{~mL}$ using nitrogen gas (N-EVAP 111; Organomatic, Berlin, Mass.). Additions of $2.5 \mathrm{~mL} \mathrm{MeOH}$ and $2.0 \mathrm{~mL}$ THF were made to the sample to achieve a final volume of $5.0 \mathrm{~mL}$. Samples were vortexed and filtered through a 0.2 $\mu \mathrm{m}$ polytetrafluoroethylene (PTFE) filter (model Econofilter PTFE 25/20; Agilent Technologies, Wilmington, Del.) before HPLC analysis.

\section{Carotenoid and chlorophyll \\ determination: HPLC analysis}

An HPLC unit with photodiode array detector (Agilent 1100; Agilent Technologies, Palo Alto, Calif.) was used for pigment separation. All samples were analyzed for carotenoid compounds using a Vydac $\mathrm{RP} \mathrm{C}_{18}$ $5.0 \mu \mathrm{m} 250 \times 4.6-\mathrm{mm}$ column (201TP54; Phenomenex, Torrance, Calif.) fitted with a $4 \times 3.0-\mathrm{mm}, 7.0-\mu \mathrm{m}$ guard column compartment. The column was maintained at $16^{\circ} \mathrm{C}$ using a thermostatic column compartment. Eluents were A $[75 \%$ acetonitrile, $20 \%$ methanol, $4.93 \%$ hexane, $0.05 \%$ butylated hydroxytoluene (BHT), and $0.013 \%$ triethylamine (TEA)] and B (50\% acetonitrile, 25\% THF, $24.98 \%$ hexane, and $0.013 \%$ TEA). The flow rate was $0.7 \mathrm{~mL} \cdot \mathrm{min}^{-1}$ and the gradient was $100 \%$ eluent A for $30 \mathrm{~min}$, $50 \% \mathrm{~A}$ and $50 \% \mathrm{~B}$ for $2 \mathrm{~min}, 100 \% \mathrm{~B}$ for $2 \mathrm{~min}$, and $50 \% \mathrm{~A}$ and $50 \% \mathrm{~B}$ for $2 \mathrm{~min}$. The eluent was returned to $100 \%$ A for $10 \mathrm{~min}$ before the next injection. Eluted carotenoid and chlorophyll compounds from a $20-\mu \mathrm{L}$ injection were detected at $452 \mathrm{~nm}$ (carotenoid pigments and internal standard), $652 \mathrm{~nm}$ for chlorophyll $a(\mathrm{Chl} a)$, and $665 \mathrm{~nm}$ for chlorophyll $b$ (Chl $b)$, with data collected, recorded and integrated using 1100 HPLC ChemStation Software (Agilent Technologies). Peak assignment was performed by comparing retention times and line spectra obtained from the photodiode array detection with authentic standards (lutein from Carotenature, Lupsingen, Switzerland; $\beta$-carotene, Chl $a$, and Chl $b$ from Sigma Chemical Co.). Concentrations of external standards were determined spectrophotometrically using the following $E_{1}^{1 \%} \mathrm{~cm}$ values: lutein, 2550 in ETOH, $\lambda_{\max }=445 \mathrm{~nm}$; $\beta$-carotene, 2592 in hexane, $\lambda_{\max }=452 \mathrm{~nm}$; Chl $a, 819$ in ETOH, $\lambda_{\max }=665 \mathrm{~nm}$; and $\mathrm{Chl}$ $b, 441$ in ETOH, $\lambda_{\max }=649 \mathrm{~nm}$ (Davies and Köst, 1988). Spinach standard reference material (Slurried Spinach 2385; National Institute of Science and Technology, Gaithersburg, Md.) was used for method validation.

\section{Statistical analysis}

Main effects were analyzed by one-way analysis of variance using SAS software (SAS Institute, Cary, N.C.). The relationship between experimental dependent variables and radiation cycle treatments were determined by regression analysis. Orthogonal polynomials were used to study changes associated with increasing radiation cycles by partitioning the sum of squares into components that were associated with linear and quadratic terms (Nogueira, 2004).

\section{Results and Discussion}

Biomass increases occurred when radiation cycles were decreased from 48-h to 2-h, with the largest kale FM production occurring under the 2-h radiation cycle treatment. Garner and Allard (1931) reported increases in biomass in response to decreases in radiation cycle treatments for a number of plant species. Biomass increases occurred in beet (Beta vulgaris L.) and soybean (Glycine max L. Merr.) as radiation cycles were decreased from 24-h to cycles of $10-\mathrm{min}$ and $2-\mathrm{h}$, respectively. Biomass increases were also reported for tomato, lettuce, and wheat as radiation cycles decreased from 16:8 h to $60: 30 \mathrm{~min}$ (irradiance/dark conditions; Morrow et al., 1987). However, one of the varieties of wheat had a minor decrease in biomass as radiation cycles decreased, decreasing slightly from 86.5 to $82.4 \mathrm{~g} / \mathrm{plant}$.

Kale shoot tissue fresh weight (FM) responded ( $P \leq 0.001)$ to increases in radiation cycle treatments and ranged from 57.3 to $40.2 \mathrm{~g} / \mathrm{plant}$ for the 2-h and $24-\mathrm{h}$ radiation cycles (Table 1). Kale shoot tissue dry weight (DM) responded $(P \leq 0.001)$ to increases in radiation cycle treatments and ranged from 3.6 to $4.8 \mathrm{~g} /$ plant $^{-1}$ for the $48-\mathrm{h}$ and $12-\mathrm{h}$ radiation cycles (Table 1). Kale FM decreased, then increased in a quadratic response $[\mathrm{FM}=$ $492.0-8.8($ CYCLE $)+0.1\left(\mathrm{CYCLE}^{2}\right) ; R^{2}=$ $0.39, P \leq 0.001]$ as the radiation cycle treatments increased from 2 to $48 \mathrm{~h}$, whereas kale DM first increased, then decreased $[\mathrm{DM}=38.2-0.27$ (CYCLE) $+0.002(\mathrm{CY}$ $\left.\left.\mathrm{CLE}^{2}\right) ; R^{2}=0.27, P \leq 0.001\right]$ over increasing radiation cycle treatments (Table 1 ). The largest FM was observed at the 2-h radiation cycle, whereas the largest DM accumulation occurred during the 12 -h radiation cycle treatment. Radiation cycle treatments also influenced the percent dry matter $(\% \mathrm{DM}$; $P \leq 0.001$ ) found in the kale shoot tissues. The \%DM ranged from 7.9 to $9.4 \%$ for the 2-h and 24-h radiation cycle (Table 1). The $\% \mathrm{DM}$ increased, then decreased in quadratic 
Table 1. Mean fresh and dry biomass accumulation in shoot tissues of 'Winterbor' kale grown under increasing radiation cycle treatments.

\begin{tabular}{lccc}
\hline & \multicolumn{2}{c}{ Plant biomass $^{\mathrm{y}}(\mathrm{g} /$ plant $)$} & \\
\cline { 2 - 3 }${\text { Time }(\mathrm{h})^{\mathrm{z}}}^{\mathrm{F}}$ & Fresh wt & Dry wt & Dry wt (\%) \\
\hline 2 & $57.3 \pm 2.8$ & $4.5 \pm 0.2$ & $7.9 \pm 0.2$ \\
12 & $55.3 \pm 2.4$ & $4.8 \pm 0.2$ & $8.8 \pm 0.1$ \\
24 & $40.2 \pm 2.0$ & $3.8 \pm 0.2$ & $9.4 \pm 0.1$ \\
48 & $43.0 \pm 2.0$ & $3.6 \pm 0.2$ & $8.5 \pm 0.2$ \\
Contrasts $^{\mathrm{x}}$ & $* * *$ & $* * *$ & NS \\
$\mathrm{L}$ & $* * *$ & $* * *$ & $* * *$ \\
$\mathrm{Q}$ & & & \\
\hline z & & &
\end{tabular}

Radiation cycle time period composed of $50 \%$ irradiance and $50 \%$ darkness

${ }^{y}$ Mean composition of sampled leaf tissue of three replications and 32 plants per replication $\pm \mathrm{SD}$. ${ }^{\mathrm{x}}$ Significance for linear (L) and quadratic (Q) orthogonal contrasts.

${ }_{\mathrm{NS}, * * * *}$ Nonsignificant or significance at $P \leq 0.001$ respectively.

Table 2. Mean pigment concentrations expressed on a fresh weight basis in the leaf tissues of 'Winterbor' kale grown under increasing radiation cycle treatments.

\begin{tabular}{|c|c|c|c|c|c|}
\hline \multirow[b]{2}{*}{ Time $(\mathrm{h})^{\mathrm{y}}$} & \multicolumn{5}{|c|}{ Pigment concn ${ }^{\mathrm{z}}(\mathrm{mg} / 100 \mathrm{~g}$ fresh wt) } \\
\hline & Lutein & $\beta$-carotene & Chl $a$ & Chl $b$ & Total Chl \\
\hline 2 & $11.2 \pm 0.2$ & $9.6 \pm 0.2$ & $184.5 \pm 3.7$ & $40.5 \pm 0.7$ & $224.9 \pm 4.4$ \\
\hline 12 & $14.5 \pm 0.6$ & $13.1 \pm 0.5$ & $236.3 \pm 12.0$ & $56.9 \pm 2.5$ & $293.2 \pm 14.4$ \\
\hline 24 & $12.8 \pm 0.3$ & $8.3 \pm 0.3$ & $235.1 \pm 6.3$ & $58.1 \pm 1.4$ & $293.3 \pm 7.5$ \\
\hline 48 & $11.6 \pm 0.2$ & $10.3 \pm 0.2$ & $197.9 \pm 3.8$ & $41.6 \pm 0.9$ & $239.4 \pm 4.6$ \\
\hline Contrasts $^{\mathrm{x}}$ & NS & NS & NS & NS & NS \\
\hline $\begin{array}{l}\mathrm{L} \\
\mathrm{Q}\end{array}$ & $* * *$ & NS & $* * *$ & $* * *$ & $* * *$ \\
\hline 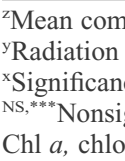 & $\begin{array}{l}\text { on of sampl } \\
\text { time period } \\
\text { linear (L) a } \\
\text { ant or signifi } \\
11 a \text {; Chl } b \text {, }\end{array}$ & $\begin{array}{l}\text { tissue of th } \\
\text { osed of } 50 \% \\
\text { dratic (Q) o } \\
\text { at } P \leq 0.00 \\
\text { ohyll } b \text {. }\end{array}$ & $\begin{array}{l}\text { plications and } \\
\text { iance and } 50 \% \\
\text { onal contrasts. } \\
\text { ectively. }\end{array}$ & $\begin{array}{l}\text { ants per re } \\
\text { ness. }\end{array}$ & $\pm \mathrm{SD}$ \\
\hline
\end{tabular}

Table 3. Mean pigment concentrations as a function of dry weight in the leaf tissues of 'Winterbor' kale grown under increasing radiation cycle treatments.

\begin{tabular}{lcc}
\hline & \multicolumn{2}{c}{ Pigments $^{\mathrm{z}}\left(\mathrm{mg} \cdot \mathrm{g}^{-1}\right.$ dry wt $)$} \\
\cline { 2 - 3 } Time $(\mathrm{h})^{\mathrm{y}}$ & Lutein & $\beta$-carotene \\
\hline 2 & $1.02 \pm 0.02$ & $0.87 \pm 0.01$ \\
12 & $1.19 \pm 0.03$ & $1.07 \pm 0.02$ \\
24 & $0.94 \pm 0.02$ & $0.62 \pm 0.03$ \\
48 & $0.99 \pm 0.02$ & $0.88 \pm 0.02$ \\
Contrasts & $*$ & Ns \\
L & Ns & $*$ \\
Q & &
\end{tabular}

${ }^{\mathrm{z}}$ Mean composition of sampled leaf tissue of three replications and 32 plants \pm SD.

${ }^{y}$ Radiation cycle time period composed of $50 \%$ irradiance and $50 \%$ darkness.

${ }^{\mathrm{x}}$ Significance for linear (L) and quadratic (Q) orthogonal contrasts.

NS, ${ }^{*}$ Nonsignificant or significance at $P \leq 0.05$ respectively.

response to increases in radiation cycle treatments $[\% \mathrm{DM}=7.6+0.1(\mathrm{CYCLE})-$ $\left.0.0001\left(\mathrm{CYCLE}^{2}\right) ; R^{2}=0.54, P \leq 0.001\right]$.

Kale leaf tissue lutein concentrations responded to increases in radiation cycles $(P \leq 0.001)$. Maximum lutein accumulation (14.5 mg/100 g FM) occurred under the 12 -h radiation cycle treatment, whereas the lowest lutein concentration $(11.2 \mathrm{mg} / 100 \mathrm{~g}$ FM) occurred for the 2-h radiation cycle treatment. Lutein concentrations increased, then decreased in a quadratic response [lutein = $11.5+0.19(\mathrm{CYCLE})-0.0004\left(\mathrm{CYCLE}^{2}\right)$; $\left.R^{2}=0.27, P \leq 0.001\right]$ to increasing radiation from both genetic and environmental effects (Kopsell et al., 2004). In the current study, the largest chlorophyll accumulation occurred for the 24-h radiation cycle, whereas the highest accumulation of carotenoid pigments occurred under the $12-\mathrm{h}$ radiation cycle.

The carotenoid content of vegetable crops is normally reported on an FM basis to equate to typical consumption patterns (Holden et al., 1999); however, because of the popularity of dried plant materials in dietary capsules as antioxidants sources, concentrations of the kale leaf tissue pigments were also calculated on a DM basis (Table 3). Radiation cycle treatments influenced lutein $(P \leq 0.001)$ and $\beta$-carotene DM accumulations $(P \leq 0.001)$. The lutein DM concentrations decreased linearly with increasing radiation cycle treatments [lutein $\mathrm{DM}=1.1$ 0.002 (CYCLE); $r^{2}=0.09, P=0.036$ ]. The $\beta$-carotene DM concentrations increased, then decreased in a quadratic response to increasing radiation cycle treatments $[\beta$-carotene $\mathrm{DM}=1.0-0.02(\mathrm{CYCLE})+0.0003\left(\mathrm{CYCLE}^{2}\right) ;$ $\left.R^{2}=0.16, P=0.021\right]$.

Kale leaf tissue biomass and lutein and $\beta$-carotene concentrations changed in response to increases in radiation cycle treatments. Lutein and $\beta$-carotene concentrations, expressed on both an FM and DM basis, peaked under the 12-h radiation cycle treatment, whereas kale FM was highest under the 2-h radiation cycle treatment. Results from this experiment demonstrate that maximum FM production does not always occur concurrently with maximum accumulation of chlorophyll and carotenoid pigments. Radiation cycles can be manipulated in controlled environments to maximize plant biomass production and concentrations of plant secondary compounds, such as carotenoids. Data show that kale FM carotenoid values are maximized under a 12-h radiation cycle ( $6 \mathrm{~h}$ of irradiance $/ 6 \mathrm{~h}$ of darkness). Enhancement of carotenoid pigment concentrations would be expected to increase the nutritional value of kale.

\section{Literature Cited}

(TChl, $P \leq 0.001$ ) pigments were influenced by increases in radiation cycle treatments (Table 2). Maximum $\mathrm{Chl}$ $a$ and $\mathrm{Chl} b$ levels occurred at the 12-h and 24-h radiation cycle treatments respectively. Maximum TChl accumulation occurred at the 24-h radiation cycle treatment. Chlorophyll pigment concentrations in the kale leaf tissues increased, then decreased in quadratic responses [Chl $a=179.9+4.9$ (CYCLE) $0.09\left(\mathrm{CYCLE}^{2}\right) ; R^{2}=0.42, P \leq 0.001 ; \mathrm{Chl} b=$ $38.3+0.17(\mathrm{CYCLE})-0.004\left(\mathrm{CYCLE}^{2}\right)$; $R^{2}=0.69, P \leq 0.001 ;$ and $\mathrm{TChl}=218.1+$ 6.6(CYCLE) $-0.13\left(\mathrm{CYCLE}^{2}\right) ; R^{2}=0.49$, $P \leq 0.001]$ to increases in radiation cycle treatments. Bonde (1955) reported the highest accumulation of chlorophyll in tomato occurred at an 8-h radiation cycle, with decreases in chlorophyll accumulation under 4-, 12-, and 19-h radiation cycle treatments. Previous research performed by our group has shown correlations between chlorophyll and carotenoid pigments in kale, resulting
Ames, B.N., L.S. Gold, and W.C. Willett. 1995. The cause and prevention of cancer. Proc. Natl. Acad. Sci. USA 92:5258-5265.

Berry, W., T. Hoshizaki, and A. Ulrich. 1986. The effect of ultradian and orbital cycles on plant growth in controlled ecological life support systems: CELSS'85. NASA Ames Research Center, Moffett Field, Calif. NASA. TM-88215 565-576.

Bonde, E.K. 1955. The effect of various cycles of light and darkness on the growth of tomato and cocklebur plants. Physiol. Plant. 8:913-923.

Bonde, E.K. 1956. Further studies on the effect of various cycles of light and darkness on the growth of tomato and cocklebur plants. Physiol. Plant. 9:51-59.

Davies, B.H. and H.P. Köst. 1988. Chromatographic methods for the separation of carotenoids, p. 1-185. In: H.P. Köst, G. Zweig, and J. Sherma (eds.). CRC handbook of chromatography, plant pigments Vol. 1: fat soluble pigments. CRC Press, Boca Raton, Fla. 
Densmore, R.V. 1997. Effect of day length on germination of seeds collected in Alaska. Amer. J. Bot. 84:274-278.

Garner, W.W. and H.A. Allard. 1931. Effect of abnormally long and short alterations of light and darkness on growth and development of plants. J. Agr. Res. 42:629-651.

Gottdenker, J., G. Giacomelli, and E. Durner. 2000 Supplemental lighting strategy for greenhouse strawberry production Fragaria Ananassa Duch., cv. Sweet Charlie). International Symposium on Protected Cultivation in Mild Winter Climates: Current Trends for Sustainable Technologies, Cartagena-Almeria, Spain, 7-11 Mar.

Hoagland, D.R., and D.I. Arnon. 1950. The waterculture method for growing plants without soil. Calif. Agr. Expt. Sta. Circ. 347.

Holden, J.M., A.L. Eldridge, G.R. Beecher, I.M Buzzard, S. Bhagwat, C.S. Davis, L.W. Douglass, S. Gebhardt, D. Haytowitz, and S. Schakel. 1999. Carotenoid content of U.S. foods: An update of the database. J. Food Composition Analysis 12:169-196.

Khachik, F., G.R. Beecher, and N.F. Whittaker. 1986. Separation, identification, and quantification of the major carotenoid and chlorophyll constituents in extract of several green vegetables by liquid chromatography. J. Agr. Food Chem. 34:603-616.

Koontz, H.V. and R.P. Prince. 1986. Effect of 16 and 24 hours daily radiation (light) on lettuce growth. HortScience 21:123-124.
Kopsell, D.A., D.E. Kopsell, M.G. Lefsrud, J. Curran-Celentano, and L.E. Dukach. 2004 Variation in lutein, $\beta$-carotene, and chlorophyll concentrations among Brassica oleracea cultigens and seasons. HortScience 39:361364.

Kurilich, A.C., G.J. Tsau, A. Brown, L. Howard, B.P. Klein, E.H. Jeffery, M. Kushad, M.A. Walig, and J.A. Juvik. 1999. Carotene, tocopherol, and ascorbate in subspecies of Brassica oleracea. J. Agr. Food Chem. 47: 1576-1581.

Landrum, J.T. and R.A. Bone. 2001. Lutein, zeaxanthin, and the macular pigment. Arch. Biochem. Biophys. 385:28-40.

Le Marchand, L., J.H. Hankin, L.N. Kolonel, G.R. Beecher, L.R. Wilkens, and L.P. Zhao. 1993. Intake of specific carotenoids and lung cancer risk. Cancer Epidemiol. Biomarkers Prev. 2:183-187.

Lefsrud, M.G., D.A. Kopsell, D.E. Kopsell, and J. Curran-Celentano. 2005. Air temperature affects biomass and carotenoid pigment accumulation in kale and spinach grown in a controlled environment. HortScience 40:20262030.

Lefsrud, M.G., D.A. Kopsell, R. Augé, and A.J. Both. 2006. Photoperiod influences biomass production and carotenoid accumulation in kale. HortScience 41:603-606.

Miki, W. 1991. Biological functions and activities of animal carotenoids. Pure Appl. Chem. $63: 141-146$
Morrow, R.C., R.J. Bula, and T.W. Tibbits. 1987. Orbital light/dark cycle effects on plant growth. Space Life Sciences Symposium: Three Decades of Life Science Research in Space, Washington, D.C., 21-26 June. Abstr. 16-19.

Nogueira, M.C.S. 2004. Orthogonal contrasts: Definitions and concepts. Sci. Agr. (Piracicaba, Brazil) 61:118-124

Riihimaki, M. and O. Savolainen. 2004. Environmental and genetic effects on flowering differences between northern and southern populations of Arabidopsis lyrata (Brassiceae). Amer. J. Bot. 91:1036-1045.

Sandmann, G. 2001. Carotenoid biosynthesis and biotechnological applications. Arch. Biochem. Biophys. 385:4-12.

Takano, T., K. Inada, and J. Takanashi. 1987. Trickle water and feeding systems in plant culture and light-dark cycle effects on plant growth. Adv. Space Res. 7:149-152.

Tracewell, C.A., J.S. Vrettos, J.A. Bautista, H.A Frank, and G.W. Brudvig. 2001. Carotenoid photooxidation in photosystem II. Arch. Biochem. Biophys. 385:61-69.

USDA. 2005. U.S. Department of Agriculture, Agricultural Research Service, National Nutrient Database for Standard Reference, release 18. 18 Nov. 2005. <www.nal.usda.gov/fnic/ foodcomp/Data/SR18/sr18.html>.

Zaripheh, S. and J.W. Erdman, Jr. 2002. Factors that influence the bioavailability of xanthophylls. J. Nutr. 132:531S-534S. 